\title{
Magnesium and Alzheimer's Disease: The Cholinergic Hypothesis
}

\author{
Matthias F. Heinitz \\ Rothenburg o.d.T., Deutschland
}

\section{Keywords}

Alzheimer's disease - Magnesium · Cholinergic hypothesis .

Choline esterase in erythrocytes · Acetylcholinesterase .

Butyrylcholinesterase

\section{Summary}

The cholinergic deficit in Alzheimer's disease (AD) remains the cornerstone for the understanding of chemical signal transfer. Hypofunctions of cholinergic systems are significantly involved in the signs and symptoms of senile dementia of the Alzheimer type. Cognitive deficits in $A D$ have been widely associated with dysfunction of the cholinergic system. As a diagnostic marker of AD the activity of choline esterase is evident in blood cells and serum. A decrease in the activity of choline esterase is a supporting indicator of the clinical diagnosis of AD. Magnesium is the second most abundant intracellular cation and plays an essential role as a cofactor in many enzymatic reactions. There are some reports indicating a relationship between neurotransmitter release and intracellular magnesium concentration. Magnesium is directly involved in numerous important biochemical reactions and is particularly a necessary cofactor in more than 300 enzymatic reactions and specifically in all those processes involving the utilization and transfer of adenosine triphosphate. A study in patients with different diagnoses showed low enzyme activity of choline esterase in erythrocytes. Administration of magnesium resulted in normal catalytic activity of choline esterase. The measurement of the enzyme activity of choline esterase is a possibility to prove magnesium deficiency and to verify the efficacy of magnesium administration. Magnesium deficiency, resulting from low magnesium dietary intake, is more common and may be corrected by magnesium supplementation.

\author{
Schlüsselwörter \\ Alzheimer-Krankheit · Magnesium • Cholinerge Hypothese . \\ Cholinesterase in Erythrozyten · Acetylcholinesterase . \\ Butyrylcholinesterase
}

\section{Zusammenfassung \\ Magnesium und Alzheimer-Krankheit: Die cholinerge Hypothese} Das cholinerge Defizit bei der Alzheimer-Krankheit bleibt der Eckpfeiler für das Verständnis der chemischen Signalübertragung. Unterfunktionen der cholinergen Systeme sind massgeblich an der Symptomatik der Alzheimer-Demenz beteiligt. Kognitive Defizite bei der AlzheimerKrankheit werden gemeinhin mit einer Funktionsstörung des cholinergen Systems in Verbindung gebracht. Als diagnostischer Marker der Alzheimer-Krankheit ist die Aktivität der Cholinesterase in Blutzellen und Plasma evident. Eine Aktivitätsabnahme der Cholinesterase ist ein unterstützender Indikator der klinischen Diagnose der AlzheimerKrankheit. Magnesium ist das zweithäufigste intrazelluläre Kation und spielt als Co-Faktor bei vielen enzymatischen Reaktionen eine wesentliche Rolle. Berichten zufolge gibt es einen Zusammenhang zwischen Neurotransmitter-Freisetzung und intrazellulärer Magnesiumkonzentration. Magnesium ist an vielen wichtigen biochemischen Reaktionen direkt beteiligt und stellt vor allem einen notwendigen Co-Faktor bei über 300 enzymatischen Reaktionen dar, insbesondere bei all jenen Prozessen, die eine Beteiligung und Übertragung von Adenosintriphosphat beinhalten. In einer Studie bei Patienten mit unterschiedlichen Diagnosen wurde eine niedrige Enzymaktivität der Cholinesterase in Erythrozyten gemessen. Magnesiumzufuhr führte zu einer normalen katalytischen Aktivität der Cholinesterase. Die Messung der Enzymaktivität der Cholinesterase ist eine Möglichkeit, Magnesiummangel nachzuweisen und die Wirksamkeit einer Magnesiumzufuhr zu belegen. Magnesiummangel als Folge unzureichender Aufnahme von Magnesium mit der Nahrung ist weit verbreitet und kann durch Magnesiumzufuhr korrigiert werden.

\section{KARGER

Dr. med. Matthias Heinitz

Martin-Schwarz-Weg 5, 91541 Rothenburg o.d.T., Deutschland m.heinitz@addproduction.de 


\section{Mots-clés}

Maladie d'Alzheimer - Magnésium - Hypothèse cholinergique . Cholinestérase dans les érythrocytes · Acétylcholinesterase . Butyrylcholinestérase

\section{Résumé}

Le magnésium et la maladie d'Alzheimer: I'hypothèse cholinergique Le déficit cholinergique dans la maladie d'Alzheimer (MA) reste le pilier de la compréhension du transfert du signal chimique. Les hypofonctions du système cholinergique sont significativement impliquées dans les signes et symptômes de la démence sénile de type Alzheimer. Les déficits cognitifs de la MA ont largement été associés à une dysfonction du système cholinergique. L'activité de la cholinestérase est un marqueur diagnostique de la MA évident dans les cellules sanguines et le sérum. Une diminution de l'activité de la cholinestérase est un indicateur confirmant le diagnostic clinique de la MA. Le magnésium constitue le deuxième cation intracellulaire le plus abondant et, en tant que cofacteur, il joue un rôle essentiel dans de nombreuses réactions enzymatiques. Plusieurs rapports indiquent une relation entre la libération de neurotransmetteurs et la concentration intracellulaire de magnésium. Le magnésium est directement impliqué dans de nombreuses réactions biochimiques importantes; il est notamment un cofacteur indispensable dans plus de 300 réactions enzymatiques et, en particulier, dans tous les processus impliquant l'utilisation et le transfert d'adénosine triphosphate. Une étude menée chez des patients ayant différents diagnostics a montré une faible activité enzymatique de la cholinestérase dans les éryhrocytes. L'administration de magnésium a entraîné une normalisation de l'activité catalytique de la cholinestérase. La mesure de l'activité enzymatique de la cholinestérase donne la possibilité de prouver la déficience de magnésium et de vérifier l'efficacité de l'administration de magnésium. La déficience de magnésium résultant d'un faible apport alimentaire en magnésium est plus fréquente et peut être corrigée par une supplémentation en magnésium.

\section{Introduction}

The most frequently occurring form of senile dementia is Alzheimer's disease (AD). The progression of the disease leads to a loss of cognitive abilities. For this reason, the treatment of $\mathrm{AD}$ is a great challenge for modern medicine while its cause is unknown. The illness has two distinct forms: early-onset and late-onset $\mathrm{AD}$. Late-onset $\mathrm{AD}$, i.e. senile dementia of the Alzheimer type (SDAT), is also referred to as the sporadic form (90-95\%). This form occurs much more frequently than early-onset $\mathrm{AD}$ (i.e. the genetic form) (5-10\%). It is as yet unclear whether the amyloid plaques and neurofibrillary tangles are the cause of AD or simply the result of other pathological processes.

A multitude of patho-anatomical, biochemical and neurophysiological study results have led to the discussion of a number of different hypotheses regarding the patho- genesis of AD. AD is the most common form of dementia. Many risk factors have been defined and environmental factors, nutrition, some vitamins, minerals, and trace elements have been investigated.

\section{The Cholinergic Hypothesis}

The cholinergic hypothesis assumes that the cognitive deficits associated with AD can be attributed to the reduced function of the cholinergic neurotransmitter system. Indications for this hypothesis are the loss of cholinergic neurons in Alzheimer's patients and a correlation between cholinergic deficits and cognitive disorders.

The synthesis of acetylcholine (ACh) follows a simple scheme. ACh is synthesized from acetyl coenzyme A (acetyl-CoA) and choline by an enzyme known as choline acetyltransferase (ChAT). The acetyl-CoA, which serves as a donor, derives from pyruvate generated by the glucose metabolism in the mitochondria.

ACh is metabolized by esterases. Several species of specific esterases exist. Two of them are essential for ACh metabolism: acetylcholinesterase (AChE) and butyrylcholinesterase (pseudocholinesterase) (BuChE). ACh is expressed in neurons, muscle cells, and certain hematopoetic cells.

\section{Alzheimer's Disease and Acetylcholinesterase and Butyrylcholinesterase Activity in Blood Cells and Plasma}

The range of examinations regarding the diagnosis of $\mathrm{AD}$ is wide. Examination methods from biochemistry contribute to casting light on the interconnections of biochemical processes. Cholinergic function in the central nervous system is a major factor for cognitive impairment in $\mathrm{AD}$ and, accordingly, $\mathrm{AChE}$ and BuChE activity in the blood and cerebral spinal fluid have been proposed as markers for the disease. However, results have been contradictory $[1,2]$, or they suggest that the activity of cholinergic markers is decreased only in severely affected patients $[3,4]$.

A study of Von Bernhardi et al. [5] compared AChE and $\mathrm{BuChE}$ as markers for $\mathrm{AD}$. Choline esterase (ChE) activity was measured in erythrocytes, lymphocytes, and platelets [5]. Low ChE activity in lymphocytes was the best discriminator for AD. Because it was already low at very early stages of $\mathrm{AD}, \mathrm{ChE}$ could be helpful as an early biomarker of differential diagnosis for the follow-up of patients during their early stages of cognitive impairment. In contrast, the AChE activity of erythrocytes was higher in patients with vascular dementia.

The aim of a recent study by Zhang et al. [6] was to investigate the cholinergic deficit in $\mathrm{AD}$ and to identify 
candidate blood biomarkers for the diagnosis of the disease. 29 elderly Chinese patients diagnosed with AD and 33 age-matched controls were selected. The results showed that AChE activity in plasma was significantly lower in the $\mathrm{AD}$ group than in normal controls. The BuChE activity did not show any differences between the $\mathrm{AD}$ and the control group. AChE activity and mRNA level of nicotinic ACh receptors in the blood leukocytes of elderly patients were significantly lower in the AD group than in controls [6].

\section{Cholinergic Deficits in the Human Brain and a Model of Cholinergic Deficits}

Cognitive deficits in neuropsychiatric disorders, such as $\mathrm{AD}$, have been related to cholinergic deficits. Different markers of cholinergic function to assess the best biomarker of cognitive deficits associated with cholinergic hypoactivity were compared. ACh levels, ChAT, and AChE activity in the postmortem frontal cortex of AD patients showed a significant correlation with cognitive deficits. In the frontal cortex of rats with a selective cholinergic lesion, all cholinergic parameters measured (ACh levels, ChAT, and AChE activities in vitro and in vivo basal ACh release) were significantly reduced. These results suggest that determination of AChE activity may be used as an effective first step method to evaluate cholinergic deficits [7].

\section{Magnesium and the Catalytic Activity of Cholinesterase in Erythrocytes}

While a reduction of $\mathrm{ChE}$ activities and normal age-associated changes in the brain of elderly patients are known [8], much larger reductions have been shown in SDAT and are considered to be part of the disease process [9]. A comparable reduction in erythrocyte AChE activity in endogenous depression has been reported [10]. ChE activity in erythrocytes (EChE) has been chosen as a parameter of magnesium deficiency for a study by the author [11].

A significant loss of activity of the EChE was proven in 11 volunteers among a group of 100 patients at a long-term hospital. As a result, there was an increase of the catalytic activity of ChE after the provision of magnesium DLaspartate in the reference range. After stoppage of the magnesium DL-aspartate supplementation, a return to the initial figures could be found. No simultaneous rise of the $\mathrm{ChE}$ level in the serum could be detected. ChE was assayed according to the procedure of Boehringer Mannheim [11, 12]. To our knowledge, this study is the first to test the hypothesis that magnesium intake is related to an increase of a low catalytic activity of the EChE in the reference range.
Intraerythrocytary $\mathrm{ChE}$ is a more differentiating indicator for the degree of activity of the enzyme than ChE in the serum. Reduced EChE values are raised to the standard by magnesium. Reduced intraerythrocytary concentrations of ChE are presumably an indication of intracellular hypomagnesemia. There was an improvement of the findings in the patients with magnesium deficiency (muscular titanic form: cramps; vascular form: arrhythmia).

Nachmansohn and Machado were the first (1943) to discover an ACh-forming enzyme system in mammal brains, which they called cholinacetylase (choline acetyltransferase/ChAT), and described potassium and magnesium as cofactors $[13,14]$.

ACh is formed from choline and acetyl-CoA by the ChAT enzyme. It is decelerated by $\mathrm{Ca} 2+$ and activated by $\mathrm{Mg} 2+[15,16]$. Pyruvate is converted back into acetyl$\mathrm{CoA}$ as the final product of the glycolysis. Catalysis occurs by means of pyruvate dehydrogenase (in fact, pyruvate dehydrogenase complex) while it is the most important enzyme providing acetyl-CoA. The activation is caused by pyruvate and magnesium.

In the presence of $\mathrm{Mg} 2+$ ions, a magnesium adenosine triphosphate (ATP) complex originates. In the ATP-dependent phosphotransferases, the magnesium ATP complex represents the substrate of these enzymes. These enzymes, e.g. hexokinase, are not capable of catalyzing the phosphorylation of their substrates in the absence of magnesium ions.

The calcium antagonistic effect of magnesium is of significance. Magnesium blocks calcium channels and thus the inflow of calcium, e.g. into synaptic heads (thereby reducing transmitter release), into the smooth vascular muscles and the cardiac cell.

\section{Discussion}

A dysfunction of the cholinergic system occurs in some degenerative diseases of the brain, such as AD. The progression of $\mathrm{AD}$ is accompanied by a strong reduction in the activity of ChAT in several cerebral structures, especially in the cortex, the hippocampus, and the amygdala, and a reduction in the biosynthesis of ACh [17].

Magnesium is a cofactor in the synthesis of ACh by ChAT. In the case of magnesium deficiency, there is a reduction of the enzyme activity (e.g. in erythrocytes), while administrations of magnesium lead to a rise in the catalytic activity of the enzyme. Low activity of the intraerythrocytary cholinesterase signals a substantial magnesium deficit.

In $\mathrm{AD}$, the cholinergic deficit in the brain correlates with the number of plaques and the degree of mnemic functional disorders, which can be attributed to the progressive cortical loss of synapses and reduced glucose metabolism. 
A magnesium deficiency is diagnostically not unproblematic. As a result of its distribution to the tissues, magnesium frequently cannot be detected due to low values in the blood. Clinical symptoms of a magnesium deficiency express themselves above all in cramps as a result of neuromuscular hyperexcitability as well as in cardiac arrhythmia. An imbalance between potassium and magnesium is the cause of this. The stimulating potassium effect is insufficiently decelerated intracellularly in magnesium deficiency.

The catalytic activity of enzymes in which magnesium is a cofactor, such as ChAT, ChE, and pyruvate kinase, results in a normal or low enzyme activity. Measurement of the catalytic activity of the EChE provides the possibility of assuming a deficiency situation with a low enzyme activity and proving it by substitution of magnesium.

Elsewhere nutritionists assume that in developed western countries, due to changes in lifestyle and increased consumption of processed food, dietary magnesium generally does not meet the recommended intake for adults, especially in the elderly [18]. Therefore, magnesium deficiency is not uncommon among the general population and magnesium supplementation could be beneficial in some diseased states.

\section{Disclosure Statement}

The author declares that no conflict of interest exists.

\section{References}

1 McWiliam C, Wood N, Copeland JR, Taylor WH: Erythrocyte acetylcholinesterase in elderly patients with dementia and depression compared with normal controls. Age Ageing 1990;19:104-106.

$\checkmark 2$ Shen ZX: CFS cholinesterase activity in demented and non-demented subjects. Neuroreport 1999;9:483-488.

$\checkmark 3$ Davis KL, Mobs RC, Martin D, Purohit DP, Perl DP, Lantz M, Austin G, Haroutunian V: Cholinergic markers in elderly patients with early signs of Alzheimer disease. JAMA 1999; 281:1401-1406.

4 De Kosky ST, Ikonomovic MD, Styren S, Beckett L, Winniewski S, Bennett DA, Cochram EJ, Kordower JH, Mufson EJ: Upregulation of choline acetyltransferase activity in hippocampus and frontal cortex of elderly subjects with mild cognitive impairment. Ann Neurol 2002;51:145-155.

5 Von Bernhardi R, Alarcón R, Mezzano D, Fuentes P, Inestrosa NC: Blood cells cholinesterase activity in early stage Alzheimer's disease and vascular dementia. Dement Geriatr Cogn Disord 2005;19:204-212.
6 Zhang LJ, Xiao Y, Qi XL, Shen KR, Pei JJ, Kuang SX, Liu F, Guan ZZ: Cholinesterase activity and mRNA level of nicotinic acetylcholine receptors (alpha 4 and beta 2 subunits) in blood of elderly Chinese diagnosed as Alzheimer's disease. J Alzheimers Dis 2010; 19:849-858.

7 Gil-Bea FJ, García-Alloza M, Domingues J, Marcos B, Ramirez MJ: Evaluation of cholinergic markers in Alzheimer's disease and in a model of cholinergic deficit. Neurosci Lett 2005;375:37-41.

$\checkmark 8$ Perry EK, Perry RH, Blessed G, Gomlinson $\mathrm{BE}$ : Changes in brain cholinesterase in senile dementia of the Alzheimer type. Neuropathol Appl Neurobiol 1978;4:273-277.

9 Perry EK: The cholinergic hypothesis. Br Med Bull 1986;42:63-69.

10 Milstoc M, Teodoru CV, Fieve RR, Kumbaraci T: Cholinesterase activity and the manic depressive patients. Dis Nerv Syst 1975;36:197-199.

11 Heinitz M: The effect of magnesium aspartate on the degree of activity of intraerythrocytary cholinesterase. Med Welt 1977;28:1096-1098.
12 Heinitz M: Trace elements in gerontology; in Frey R (ed): Trace Elements. 1979, pp 32-34.

13 Nachmansohn D, Berman M: Studies on choline acetylase. J Biol Chem 1964;165:551563.

14 Nachmansohn D, Hestrin S, Voripaieff H: Enzymatic synthesis of a compound with acetylcholine-like biological activity. J Biol Chem 1949;180:875-877.

15 Feldberg W, Hebb C: The effects of magnesium ions and of creatine phosphate on the synthesis of acetylcholine. J Physiol 1947;106:8-17.

16 Falk H: Contribution on the Bacterial Synthesis of Acetylcholine. Inauguraldissertation. Freiburg i.Br., 1955.

17 Wilcock GK, MM Esiri: Alzheimer's disease correlation of cortical choline acetyltransferase activity with the severity of dementia and histological abnormalities. J Neurol Sci 1982;57:407-417.

18 Vaquero MP: Magnesium and trace elements in the elderly: intake, status and recommendations. J Nutr Health Aging 2002;6:147-153. 